\title{
Die Versorgung Deutschlands mit metallischen Rohstoffen (Erzen und Metallen)
}

von

\section{Prof. Dr. P. Krusch}

Abteilungsdirigent a. d. Kgl. Geologischen Landesanstalt Dozent für Erzlagerstättenlehre a. d. Kgl. Bergakademie zu Berlin

Mit 97 Abbildungen im Text

Leipzig

Verlag von Veit \& Comp.

1913 
